\title{
Sistem Mekanis dari Objek Wisata sebagai Daya Tarik (Studi Kasus Jembatan Kota Intan Kota Tua Jakarta)
}

\author{
Ali Ramadhan \\ Program Studi Desain Produk, Universitas Mercu Buana \\ Email: ardesign26@gmail.com
}

\begin{abstract}
ABSTRAK
Sistem mekanis merupakan suatu sistem yang berada di dalam sebuah objek benda. Keberadaannya dapat memberikan nilai tambah dari objek benda karena dapat memberikan suatu daya tarik tersendiri bagi pengguna atau orang yang memanfaatkannya. Jembatan Kota Intan merupakan salah satu jembatan yang dijadikan objek wisata sejarah yang memiliki nilai sejarah dalam pembentukan kota Jakarta. Berkitan dengan sejarah dari Jembatan Kota Intan, jembatan tersebut memiliki suatu sistem mekanis yang dapat memberikan nilai tambah sebagai objek wisata sejarah. Saat ini, sistem mekanis yang ada pada jembatan tersebut sudah tidak dapat digunakan karena jembatan tersebut hanya dilihat sebagai objek wisata saja. Dengan menggunakan metode kualitatif, penelitian ini dapat memberikan penjelasan secara deskriptif untuk memberikan pengetahuan mengenai potensi yang terdapat pada suatu sistem mekanis dari sebuah jembatan. Pemanfaatan suatu sistem mekanis pada Jembatan Kota Intan dapat menghadirkan kembali suasana yang pernah ada pada masanya. Adanya unsur tersebut mampu memberikan dampak positif bagi lingkungannya. Dengan adanya koordinasi yang baik antara pemerintah daerah yang mengurus objek wisata sejarah dengan penjaga objek wisata tersebut, maka suatu objek benda yang memiliki sistem mekanis akan memiliki daya tarik karena akan mampu menghadirkan pengetahuan mengenai sejarah mengenai objek benda tersebut.
\end{abstract}

Kata Kunci: Sistem Mekanis, Daya Tarik, Objek Wisata, Jembatan Kota Intan.

\section{PENDAHULUAN \\ Latar Belakang}

Sistem mekanis merupakan suatu sistem yang terdapat di suatu benda. Benda yang di dalamnya memiliki sistem mekanis biasanya merupakan benda yang memiliki sifat digunakan oleh orang. Keberadaan suatu sistem mekanis yang merupakan "penggabungan komponen untuk membuat sesuatu dapat bergerak" (Robert, 2011, h. 2) di suatu benda terkadang dibuat sebagai salah satu cara untuk memenuhi kebutuhan manusia untuk mempermudah pekerjaannya. Namun dalam hal ini sistem mekanis juga dapat menjadi daya tarik. Hal ini dikarenakan tidak sedikit benda yang menarik perhatian menggunakan sistem mekanisnya. Selain itu dengan adanya suatu sistem mekanis di suatu benda maka akan memberikan pengetahuan mengenai berbagai macam hal yang berkaitan tidak hanya dengan bendanya sendiri namun juga sebagai bahan studi yang lain.

Jembatan kota intan di kota tua Jakarta, merupakan salah satu benda yang memiliki daya tarik tesendiri. Karena daya tarik yang dihasilkan salah satunya adalah sistem mekanis yang terdapat pada jembatan tersebut. Karena sistem mekanis di jembatan tersebut sudah ada sejak jembatan tersebut didirikan. Namun pada saat ini sistem mekanis dari jembatan tersebut sudah tidak dapat dioperasikan. Sistem mekanis yang terdapat pada jembatan kota intan dapat menghadirkan suasana yang mewakili zamannya. Karena dengan penerapan sistem mekanis pada jembatan tersebut, tidak saja menampilkan suatu atraksi dari jembatan tersebut dan menghadirkan suasana yang berbeda.

Dalam konteks sebagai daya tarik, dengan menghadirkan suatu sistem mekanis pada suatu benda, secara langsung akan memperlihatkan suatu objek wisata memiliki potensi untuk menarik pengunjung. Karena dapat secara langsung menghadirkan unsur untuk memikat pengunjung agar mendatanginya seperti menghadirkan keunikan yang dapat dilihat. Daya tarik atau "kemampuan menarik atau memikat perhatian" yang dihasilkan dari suatu sistem mekanis, tidak akan lepas dari keberadaan benda sendiri. Daya tarik yang bisa diambil terdapat pada berbagai macam hal 
yang membentuknya. Terbentuknya suatu benda secara langsung akan berkaitan dengan konteks desain sebagai "salah satu bentuk kebutuhan badani dan rohani manusia yang dijabarkan melalui pelbagai bidang pengalaman, keahlian dan pengetahuannya yang mencerminkan perhatian pada apresiasi dan adaptasi terhadap sekelilingnya, terutama yang berhubungan dengan bentuk, komposisi, arti, nilai dan pelbagai tujuan benda buatan manusia" (Sachari, 2002, h. 5).

Dalam desain, suatu benda sebagai "segala sesuatu yang ada dalam alam yang berwujud atau berjasad yang berwujud padan dan bersifat tetap", juga terdapat suatu sistem mekanis yang. Sistem mekanis tersebut memiliki fungsi sebagai salah satu cara untuk membantu manusia dalam melakukan pekerjaannya. Oleh karena itu dengan adanya sistem mekanis secara tidak langsung juga telah menjadi daya tarik yang membantu menambah nilai suatu benda. Karena di dalam perkembangan desain saat ini sistem mekanis dapat menjadi tolak ukur dalam merancang suatu benda. Tolak ukur yang ada akan mempengaruhi keputusan seseorang dalam memilih suatu benda yang mampu mempermudah pekerjaannya. Oleh karena itu penelitian ini diharapkan mampu memberikan informasi mengenai akan adanya daya tarik yang dihasilkan dari keberadaan suatu sistem mekanis.

\section{Permasalahan}

Saat ini Jembatan Kota intan merupakan salah satu benda "cagar budaya" karena sebagai "benda buatan manusia, bergerak atau tidak bergerak yang berupa kesatuan atau kelompok. Atau bagian -bagiannya atau sisa-sisanya yang berumur sekurang - kurangnya 50 (lima puluh) tahun, atau mewakili masa gaya sekurang-kurangnya 50 (lima puluh) tahun serta dianggap mempunyai nilai penting bagi sejarah, ilmu pengetahuan, dan kebudayaan." (Pedoman Pemintakatan Benda, 2006) yang terdapat di kawasan kota tua Jakarta. Hal ini dikarenakan, jembatan kota intan juga sudah menjadi tempat wisata. sehingga jembatan kota intan sudah seharusnya memiliki cirinya sendiri. Karena jika melihat kondisi dari suatu cagar budaya maka akan lebih baik jika benda tersebut dapat mewakili zamannya. Hal ini dikarenakan saat ini jembatan kota intan dirasa masih kurang mewakili zamannya. Karena selain objek bendanya sendiri, seharusnya juga terdapat suatu daya tarik yang dihasilkan dari sistem mekanisnya. Suatu benda dikatakan mewakili zamannya jika semua komponen yang berada didalamnya mampu memberikan pengetahuan dan kenangan yang terjadi pada masanya. Salah satu hal yang dapat memberikan daya tarik pada suatu benda khususnya objek wisata adalah dengan menghadirkan suatu atraksi. Atraksi yang dihadirkan dari objek wisata salah satunya adalah menghadirkan sistem mekanis untuk menarik perhatian orang agar dapat menarik pengunjung untuk mendatanginya.

Dalam konteks desain saat ini. Tidak hanya berbicara mengenai bentuk yang bagus. Namun juga sudah mulai membahas mengenai suatu sistem mekanik. Karena di dalam suatu benda jika hanya mengacu kepada bentuk saja maka lambat laun benda tersebut mulai dilupakan. Namun jika ditambah dengan menghadirkan sistem mekanis, maka akan menjadi nilai tambah suatu benda mampu bertahan lama.

\section{Rumusan Masalah}

Setelah pembatasan masalah yang dilakukan maka didapat rumusan masalah dalam bentuk pertanyaan:

1. Bagaimana suatu benda khususnya objek jembatan kota intan dapat memberikan suatu daya tarik

2. Bagaimana sistem mekanis jembatan kota intan dapat menjadi daya tarik suatu benda

Adanya pertanyaan tersebut dikarenakan pada masa kini jembatan kota intan dijadikan "cagar budaya" oleh pemerintah kota Jakarta. Dengan fakta yang ada saat ini Sistem mekanis dari 
jembatan tidak dikelola dengan baik karena kurangnya perhatian mengenai potensi yang ada pada jembatan tersebut sehingga sistem mekanis pada jembatan tidak dapat digunakan. Dengan adanya sistem mekanis yang aktif dapat meningkatkan daya tarik yang menjadi nilai tambah dari jembatan itu sendiri sebagai objek wisata.

\section{METODE PENELITIAN}

Metode penelitian pada dasarnya merupakan cara ilmiah untuk mendapatkan data dengan tujuan tertentu. Metode yang digunakan dalam melakukan peneltian mengenai jembatan kota intan adalah metode penelitian kualitatif. Penggunaan metode kualitatif bertujuan untuk "menjelaskan fenomena dengan sedalam-dalamnya melalui pengumpulan data. Dengan menekankan pada persoalan kedalaman (kualitas) dan bukan banyaknya (kuantitas) data" (Burhan, 2004, h. 122). Dalam bukunya yang berjudul "Riset Komunikasi" Rachmat Kriyantono (2006) menjelaskan bahwa penelitian yang menggunakan metode kualitatif memiliki ciri:

- Perekaman yang sangat hati-hati terhadap apa yang terjadi dengan catatan di lapangan dan tipe lain dan bukti dokumenter.

- Analisis data lapangan

- Melaporkan hasil termasuk deskripsi detail, quotes (kutipan) dan komentar (Kriyantono, 2006, h.58). Dan selain metode tersebut. Dalam penelitian ini menggunakan beberapa metode pengumpulan data.

\section{Metode pengumpulan data}

Metode pengumpulan data adalah "bagian instrumen pengumpulan data yang menentukan berhasil atau tidaknya suatu penelitian" (Sugiyono, 2005). Dalam penelitian ini metode pengumpulan data yang dilakukan adalah:

- Studi Pustaka yang digunakan dengan cara mempelajari buku ilmu pengetahuan dan makalah ilmiah yang berhubungan dengan masalah yang dibahas. Studi pustaka yang digunakan berkenaan dengan sejarah serta sistem operasional Jembatan kota Intan.

- Wawancara dengan responden berupa orang yang berkaitan langsung dengan objek penelitian jembatan Kota Intan yaitu penjaga dan orang yang sedang berada disekitarnya.

- Observasi yang digunakan sebagai salah satu cara untuk mengamati kegiatan yang terdapat di sekitar jembatan kota intan.

\section{HASIL DAN PEMBAHASAN}

\section{Hasil}

\section{Jembatan kota intan}

Jembatan kota intan berada di kawasan wisata kota tua Jakarta. Tepatnya berada di Jl Kali Besar Barat Jakarta Utara. Areal wisata Jembatan Kota Intan berada di sisi barat dari kawasan Kota Tua dan sangat dekat dengan pusat Kota Tua yakni Museum Fatahillah. Posisi jembatan kota intan berada di atas Kali Besar yang dahulu dijadikan kanal oleh VOC. Sehingga "pada masa pemerintahan VOC kanal tersebut sering dilewati oleh kapal yang mengangkut kebutuhan sehari - hari. Jembatan kota intan dikenal sebagai salah satu jembatan yang tertua dan berada di Indonesia. Dikatakan tertua karena jembatan tersebut sudah ada sejak tahun 1628. Pada awalnya, jembatan tersebut difungsikan sebagai gerbang dari benteng yang dibuat oleh VOC" (Sejarah Perkembangan Kota, 2006)

Pada perkembangannya, jembatan tersebut menghubungkan dua sisi jalan kali besar barat. Pada saat itu fungsi jembatan menghubungkan benteng VOC dengan benteng Inggris. Untuk saat ini, jembatan tersebut sudah tidak difungsikan sebagai penyeberangan Hampir setiap bagian dari 
jembatan tersebut menggunakan material kayu sebagai pembentuknya. Dari tahun 1972 hingga saat ini jembatan tersebut sudah di alih fungsikan sebagai salah satu objek wisata dan cagar budaya oleh pemerintah DKI Jakarta yang berada di kawasan kota tua.

\section{Sistem mekanis jembatan kota intan}

Pada Jembatan Kota Intan terdapat semacam pengungkit untuk menaikan sisi bawah jembatan. Penggunaan tenaga manusia sebagai penjaga akan difungsikan untuk menarik tali pengungkit jika ada kapal yang akan melewati jembatan menuju kota. Jembatan kota intan termasuk kepada kategori "jembatan jungkit" yang memiliki sistem mekanis dengan ditarik menggunakan tenaga manusia untuk menggerakannya.

Sistem tersebut awalnya dipakai dalam bentuk gerbang suatu kerajaan atau kastil. Kastil abad pertengahan biasanya dipisahkan oleh selokan atau parit, dilintasi oleh jembatan kayu. Penggunaan sistem mekanis pada jembatan kota intan pada awalnya juga dimaksudkan untuk gerbang dari masuknya kapal yang akan masuk ke dalam benteng VOC.
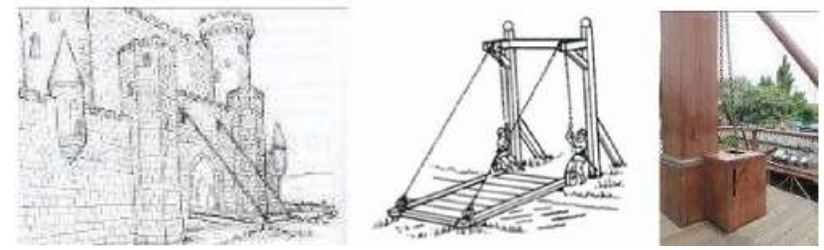

Gambar 1. Ilustrasi Kondisi Jembatan Kota Intan Dan Sistem Mekanis Jembatan

Sistem mekanis yang ada pada jembatan berupa pergerakan naik turun menggunakan tali atau rantai yang terdapat pada "mesin kerek". Pergerakan tersebut dimaksudkan untuk menutup dan membuka jembatan. Selain itu tenaga manusia yang digunakan pada sistem ini dimkasudkan sebagai operator dari jembatan untuk menaikkan dan menurunkan jembatan. Selain tenaga manusia, untuk menggerakkan jembatan tersebut menggunakan rantai yang dihubungkan dengan mesin kerek yang memiliki pengunci untuk menahan secara sementara disaat jembatan tersebut dinaikkan.

Jembatan tersebut memiliki komponen yang menjadi ciri dan dimiliki jembatan jungkit kota intan yaitu didominasi material kayu yang disertakan dengan rantai untuk mengangkat jembatan. Penggunaan material kayu dimaksudkan agar mudah untuk diangkat. Selain itu penggunaan rantai pada jembatan difungsikan sebagai penarik jembatan. Sistem naik turun jembatan kota intan dipengaruhi oleh beberapa unsur yaitu gaya tarik yang dihasilkan oleh tenaga manusia. Serta gerak rotasi yang difungsikan untuk perputaran jembatan pada porosnya.

\section{Gaya tarik dan gerak rotasi}

Diketahui bahwa sistem mekanis jembatan kota intan dinaikkan dan diturunkan menggunakan mesin kerek yang secara manual menggunakan tenaga manusia. Selain itu juga pada mesin tersebut terhubung rantai yang berfungsi untuk mengangkat jembatan. Pergerakan yang berada pada jembatan tersebut disebabkan oleh adanya gaya tarik. Gerak tersebut menghasilkan perubahan posisi benda (jembatan) Posisi yang awalnya datar menjadi terangkat.

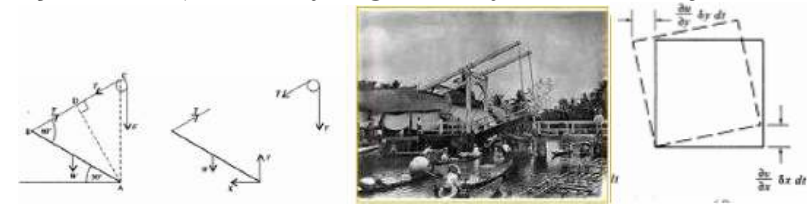

Gambar 2. Gaya Tarik Dan Gerak Rotasi Pada Jembatan 
Perubahan yang dihasilkan dari terangkatnya jembatan tersebut mampu menghadirkan kondisi masa lalu yang bertujuan untuk memberikan ruang kepada kapal yang akan melewati jembatan yang juga berfungsi sebagai gerbang. Berdasarkan dari adanya gaya tarik yang dilakukan terhadap jembatan tersebut maka menghasilkan perubahan pada jembatan. Perubahan tersebut menghasilkan perputaran jembatan terhadap sumbunya yang menghasilkan jembatan tersebut terangkat.

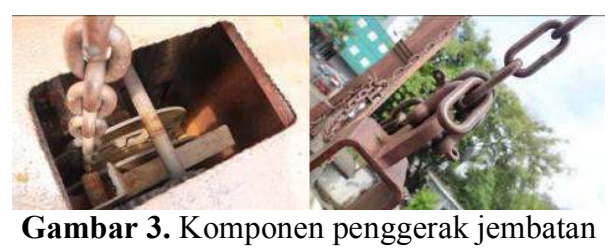

Terangkatnya jembatan tersebut dihasilkan dari adanya gerakan yang dihasilkan dari penarikan rantai menggunakan mesin kerek yang dioperasikan secara manual. Selain itu dari adanya perubahan yang dihasilkan dari gerak rotasi maka posisi jembatan yang terangkat dapat difungsikan sebagai penutup jalan. Pergerakan jembatan tersebut dihasilkan juga dari saling berhubungannya setiap komponen pada jembatan tersebut. Seperti terhubungnya rantai dengan badan jembatan. Pengaturan dari penempatan rantai pada jembatan juga dibuat sejajar dengan pegangan jembatan serta dihubungkan dengan bagian ujung jembatan. Dengan adanya gerak rotasi yang terdapat pada jembatan kota intan tersebut maka secara tidak langsung jembatan tersebut juga sudah menghadirkan suatu atraksi.

\section{Daya tarik jembatan kota intan}

Jembatan kota intan sebagai tempat wisata, tidak akan lepas dari daya tarik yang dimiliknya. Yaitu dengan menghadirkan sebuah sejarah yang diperlihatkan dari sebuah benda. Dari jembatan yang berukuran "Panjang 30 Meter, Lebar 4,43 Meter dan dibangun pada tahun 1628" (Dimyati, 2010: 56) ini, memiliki berbagai macam cerita dari kehancuran jembatan pada tahun 1629, sering bergantinya nama jembatan yang disesuaikan dengan nama ratu Belanda yang berkuasa dan penggunaan nama yang bersifat lokal seperti "Jembatan Pasar Ayam". Hingga saat ini jembatan tersebut dijadikan "landmark" karena memiliki "bentuk visual yang menonjol untuk mempermudah orientasi, dan terlihat dari luar" (Winandari,2010: 98) dari kawasan kota tua dan digunakannya jembatan ini terkadang digunakan sebagai tempat penyelenggaraan salah satu acara ulang tahun Jakarta.

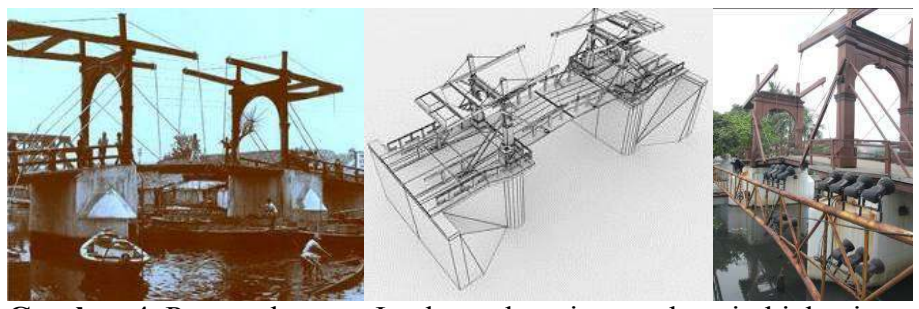

Gambar 4. Pengembangan Jembatan kota intan sebagai objek wisata

Dijadikannya Jembatan Kota Intan sebagai salah satu tempat untuk penyelenggaraan salah satu acara pada ulang tahun kota Jakarta. Maka Jembatan tersebut termasuk ke dalam objek cagar budaya yang harus dilestarikan. karena memiliki potensi sebagai objek wisata mengingat lokasi yang sangat strategis, nilai sejarah yang terkandung dan potensi wisata sebagai landmark dari tatanan transportasi era Kolonial Belanda. Untuk itu Pemerintah Daerah Provinsi DKI Jakarta telah melakukan berbagai upaya dalam merawat dan merevitalisasi Jembatan Kota Intan ini. 
Berdasarkan dari hasil wawancara yang dilakukan dengan penjaga Jembatan Kota Intan, didapatkan fakta bahwa Jembatan Kota Intan yang sekarang berdiri bukan merupakan Jembatan Kota Intan yang asli dibuat oleh pemerintahan kolonial Belanda pada waktu itu. Karena kondisi Jembatan Kota Intan dulu sempat memburuk, kayu yang sudah termakan usia, dan kekuatan konstruksi yang mungkin sudah tidah kuat lagi, maka Pemerintah Daerah Provinsi DKI Jakarta membuat replika Jembatan Kota Intan agar masyarakat kota Jakarta tetap tertarik untuk melihat salah satu peninggalan sejarah dalam bentuk objek Jembatan.

\section{Atraksi}

Jembatan Kota Intan diketahui berada di kawasan Kota Tua Jakarta. Dan didapatkan hasil bahwa Yang termasuk dalam kawasan kota tua adalah wilayah kawasan dengan luas sebesar 846 hektar dengan berbagai macam tempat yang menyediakan informasi tentang sejarah dari terbentuknya kota Jakarta. (SK Gubernur Provinsi DKI Jakarta No.34 Tahun 2006) yang didalamnya terdapat bangunan bersejarah dalam terbentuknya kota Jakarta. Objek bangunan bersejarah ini termasuk dalam satu kawasan wisata dan dikelola sepenuhnya oleh Pemerintah Daerah Provinsi DKI Jakarta dengan potensi wisata yang beragam. Namun pada perkembangannya saat ini, dikawasan Kota Tua Jakarta, banyak terdapat bangunan peninggalan zaman kolonial Belanda yang dalam bentuk terawat dan tidak terawat.

Untuk gedung yang dalam kondisi terawat lebih dikarenakan gedung tersebut dimiliki oleh pihak yang memiliki kepentingan dengan penggunaannya. Namun di satu sisi untuk gedung yang tidak terawat lebih dikarenakan pemanfaatan gedung yang digunakan sebagai tempat penampungan sampah atau barang bekas. Hal ini mengakibatkan berkurangnya minat karena bau yang dihasilkan dari adanya penampungan sampah tersebut dan secara tidak langsung mengurangi keindahan dari kawasan Kota Tua. Kondisi lingkungan dari Jembatan kota intan dibagi ke dalam dua kondisi pada saat observasi dilakukan yaitu siang dan malam hari. Kondisi panas didapatkan di kawasan Jembatan dikarenakan posisi jembatan yang kurang dipenuhi dengan pohon serta berada di ruang terbuka. Selain itu, suasana jembatan juga dipengaruhi oleh bau yang dihasilkan dari kotornya Kali Besar yang berada di bawah jembatan. Sedangkan untuk kondisi pada malam hari, Suasana jembatan mengalami perubahan. Dari suasana yang tidak lagi panas serta hadirnya cahaya yang dihasilkan dari lampu sorot yang membuat tampilan Jembatan kota Intan menjadi lebih baik. Namun kondisi tersebut tidak mempengaruhi bau yang tetap ada seperti kondisi siang hari.

\section{Aksesbilitas}

Kawasan Kota Tua berlokasi di wilayah kotamadya Jakarta Utara dan Jakarta Barat. Lokasi kawasan yang dekat dengan kawasan wisata Ancol di Jakarta Utara ini menyebabkan kawasan Kota Tua memiliki potensi tinggi untuk dijadikan kawasan wisata khususnya "wisata sosial budaya" terpadu selain sebagai kawasan sejarah. Letak kawasan ini didukung dengan akses menuju kawasan Kota Tua yang sangat baik. Terdapat berbagai macam akses untuk mencapai kawasan tersebut.

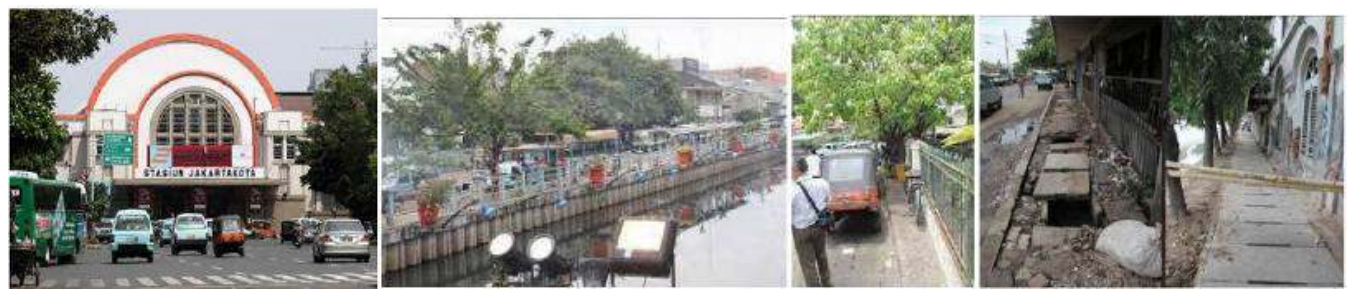

Gambar 5. Aksesbilitas Jalan Menuju Jembatan kota Intan 
Kawasan Kota Tua dapat dicapai dari stasiun kereta api di Jakarta, yaitu Stasiun Kota, sehingga masyarakat dari luar Jakarta yang ingin mengakses Kawasan kota tua menjadi mudah. Mengingat stasiun tersebut merupakan salah satu pemberhentian kereta dari kota yang berada di luar Jakarta seperti Depok, Bogor dan Tangerang.

Melihat dari kondisi yang ada, keramaian dari kawasan kota tua sudah mulai terlihat dari stasiun lalu Museum Fatahillah. Untuk menuju Museum tersebut, pengunjung bisa memanfaatkan transportasi umum seperti bajaj atau berjalan kaki. Ramainya pengunjung di kawasan Museum Fatahillah secara tidak langsung juga dipengaruhi oleh kemudahan untuk mencapainya.

Area wisata Jembatan Kota Intan berada di sisi barat dari kawasan Kota Tua dan dekat dengan pusat Kota Tua yakni Museum Fatahillah. Jarak antara Jembatan Kota Intan dengan Museum Fatahillah hanya berkisar $+/-1 \mathrm{~km}$ dan bisa ditempuh hanya dalam beberapa menit jika menggunakan sepeda atau dengan berjalan kaki. Jika berbicara mengenai akses menuju Jembatan Kota Intan dengan berjalan kaki. Akan terasa kurang nyaman dikarenakan kondisi jalan menuju jembatan tersebut kurang baik. Kondisi yang kurang baik tersebut terlihat dari buruknya kondisi trotoar untuk menuju Kawasan Jembatan. Dari terbukanya penutup saluran air. Lalu adanya penutup jalan yang menutup trotoar. Hal ini memberi kesan kurangnya perhatian terhadap akses menuju Jembatan Kota Intan. Jembatan Kota Intan dapat diakses menggunakan kendaraan pribadi atau kendaran umum. Hal ini terlihat dari adanya terminal yang berada tidak jauh dari Jembatan Kota Intan. Terminal yang berada di dekat Jembatan Kota Intan merupakan Terminal Kota. Yang berfungsi sebagai tempat pemberhentian angkutan umum. Dengan adanya angkutan umum yang berada di terminal tersebut, secara langsung telah memberikan gambaran mengenai kemudahan untuk mengakses Jembatan Kota Intan. Namun karena kurangnya perhatian dari masyarakat atau Pemerintah Daerah DKI Jakarta maka akses menuju Jembatan Kota Intan berkesan kumuh.

\section{Fasilitas}

Keberadaan Jembatan Kota Intan tidak dapat lepas dari tempat beradanya di suatu kawasan yaitu kawasan Kota Tua. Jika berbicara mengenai Kota Tua maka akan berkaitan dengan oleh luasnya kawasan Kota Tua tersebut, Pemerintah Daerah Provinsi DKI Jakarta telah melakukan beberapa upaya dalam memfasilitasi akses pengunjung untuk mengunjungi objek bersejarah yang terdapat di kawasan Kota Tua. Upaya tersebut berupa fasilitas transportasi yang diberikan kepada pengunjung seperti fasilitas penyewaan sepeda khususnya sepeda jenis onthel yang mampu memberikan nilai estetika dan pengalaman tersendiri bagi pengunjung. Selain fasilitas yang diberikan, Pemerintah Daerah Provinsi DKI Jakarta juga membuat kebijakan pendukung seperti penutupan jalan (roadblock) pada beberapa bagian jalan di beberapa tempat strategis yang diharapkan agar pengunjung dalam berjalan kaki santai untuk mengunjungi objek bersejarah yang terdapat di kawasan tersebut. Selain fasilitas yang berkaitan dengan kawasan kota tua. Objek wisata Jembatan Kota Intan juga menghadirkan fasilitas yang terdapat di dalam dan di luarnya. Fasilitas tersebut secara tidak langsung bisa dijadikan sebagai pendukung dalam menciptakan suatu daya tarik dari sebuat objek.

Untuk pengunjung yang menginginkan kemudahan untuk mencapai jembatan tersebut dapat menggunakan fasilitas pendukung yang telah ada. Selain itu, terdapat juga fasilitas yang medukung untuk wisatawan menginap seperti hotel yang berada tidak jauh dari Jembatan Kota Intan. Untuk mencapai objek Jembatan, pengunjung yang bermalam di hotel tersebut dapat mengakses jembatan tersebut dengan berjalan kaki. Selain itu, Jembatan tersebut juga terlihat dari hotel tersebut. Hal ini mampu menghadirkan suatu nilai tersendiri dalam menjadikan Jembatan Kota Intan sebagai daya tarik. 
Mengenai fasilitas selain penginapan, di sekitar Jembatan Kota Intan juga memiliki fasilitas makan dan minum dalam bentuk "restoran" dan "cafe" atau pedagang "kaki lima". Hal ini menjadikan adanya berbagai macam pilihan fasilitas makan dan minum sebagai salah satu cara untuk membantu pengunjung dalam memenuhi kebutuhan primernya.
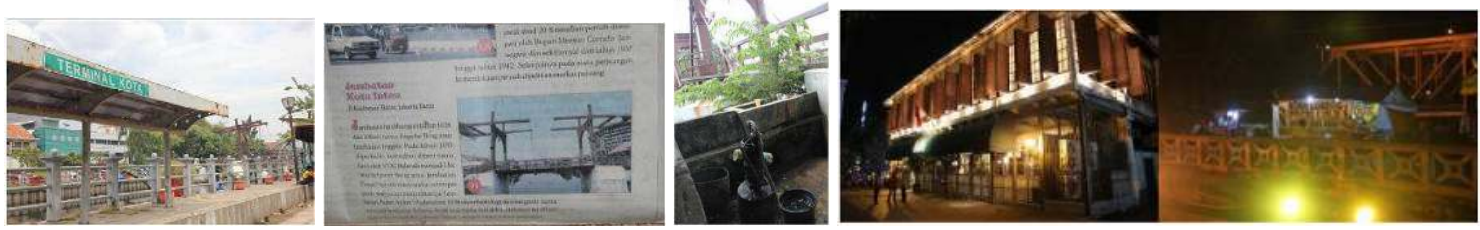

Gambar 6. Fasilitas pendukung yang terdapat di area dalam Jembatan Kota Intan

Fasilitas utama yang terdapat pada Jembatan Kota Intan adalah Jembatan itu sendiri. Dengan Jembatan Kota Intan sebagai fasilitas utama. Kondisi Jembatan cukup terawat, namun pada beberapa sisi yang rusak (harus diperbaiki) hanya diperbaiki seadanya karena minimnya perhatian reguler dari Pemerintah Daerah Provinsi DKI Jakarta. Hal ini terlihat dari adanya pagar pembatas (railing) Jembatan Kota Intan yang sudah lapuk digantikan dengan bambu seadanya. Adanya perbaikan tersebut berpengaruh kepada penilaian pengunjung jembatan tersebut. selain itu akan berpengaruh kepada kenyaman dan keamanan. Selain fasilitas jembatan itu sendiri, pada kawasan tersebut terdapat fasilitas pengairan.

Fasilitas pengairan yang disediakan di kawasan jembatan hanya berupa pompa air yang sering digunakan oleh pihak penjaga jembatan. Fasilitas tersebut tidak didukung oleh adanya fasilitas toilet umum yang seharusnya berada di dalam kawasan tersebut. Untuk mengakses fasilitas toilet maka pengunjung harus keluar dari kawasan tersebut dan berjalan kaki. Sehingga akan membutuhkan waktu yang tidak sedikit untuk mencapainya. Hal ini ditambah dengan akses masuk dan keluar pada kawasan tersebut hanya ada satu. Berkaitan dengan objek wisata, maka dalam penerapannya, pada objek wisata Jembatan Kota Intan terdapat fasilitas layanan informasi sebagai salah satu cara untuk menyampaikan informasi mengenai objek jembatan tersebut.

Pada kawasan Jembatan Kota Intan, informasi di dapatkan dari penyampaian yang dilakukan oleh penjaga. Selain itu informasi yang ada didukung juga dengan penggunaan bahan bacaan berupa brosur mengenai Kota Tua yang didalamnya memuat informasi mengenai Jembatan kota Intan. Informasi berupa brosur di tempatkan di dalam pos jaga oleh penjaga yang dkeluarkan oleh pihak Dinas Pariwisata DKI Jakarta. Hal yang sangat disayangkan karena informasi yang ada merupakan informasi yang biasa ditemukan. Dengan adanya penyedia informasi yang didapat oleh penjaga maka secara langsung akan menghadirkan adanya komunikasi. Yang sebenarnya menjadi nilai lebih untuk mendapatkan informasi sejelasnya jika dimanfaatkan secara maksimal.

Selain adanya fasilitas informasi, fasilitas hiburan juga merupakan salah satu aspek yang perlu dihadirkan pada objek wisata. Hiburan pada kawasan Jembatan Kota Intan hanya terdapat pada Jembatan itu sendiri. Dalam penerapannya, jembatan tersebut hanya menampilkan sejarah yang didapat dari perkembangannya. Selain dari fasilitas hiburan, fasilitas keamanan dalam sebuah objek wisata dapat digunakan sebagai pelengkap suatu daya tarik objek wisata. Fasilitas keamanan pada Jembatan Kota Intan didapat dari adanya keamanan yang dijaga oleh pihak penjaga sendiri. Selain itu untuk memasuki objek wisata Jembatan Kota Intan sendiri hanya menggunakan satu pintu yang digunakan untuk akses masuk. Dengan hanya disediakannya satu pintu akses. keamanan Jembatan menjadi lebih baik karena penjaga akan lebih terfokus terhadap pengunjung yang terlihat mencurigakan. 


\section{Tata laksana}

Dijadikannya Jembatan kota intan sebagai salah satu benda cagar budaya dikarenakan jembatan tersebut sudah berusia lebih dari 50 tahun dan merupakan salah satu jembatan yang dibangun oleh manusia tepatnya pada saat penjajahan Belanda (VOC). Oleh karena itu dalam penerapannya, akan lebih baik jika jembatan tersebut mendapat perhatian lebih dari pemerintah daerah khususnya Pemda DKI Jakarta. Dikarenakan pada prakteknya, di jembatan tersebut masih adanya permasalahan yang mendasar terhadap pengelolaan dari jembatan tersebut. Pada dasarnya, pengelolaan jembatan tersebut sebenarnya sudah memiliki sistem sendiri yaitu dengan adanya penjaga dari jembatan kota intan. Karena dari hasil observasi, pelaksanaan dari pengelolaan yang telah diterapkan di jembatan kota intan sendiri masih terlihat kurang mendapat perhatian. Dari adanya biaya masuk yang ditetapkan oleh penjaga sebesar Rp 5.000 tidak akan menjadi masalah jika hal tersebut dibarengi dengan informasi.

\section{Keterlibatan masyarakat}

Melihat kondisi yang ada, keberadaan Jembatan kota intan sebagai objek wisata sudah diterima keberadaannya oleh masyarakat disekitarnya. Hal ini dilihat dari tidak sedikitnya pedagang yang berjualan disekitar jembatan tersebut. Hal ini juga menjadi salah satu daya tarik tersendiri (promosi) untuk memperkenalkan jembatan kota intan sebagai salah satu tempat wisata bersejarah serta lingkungan kota tua sebagai kawasan wisata. Keberadaan objek wisata tersebut telah mampu meningkatkan perekonomian dari masyarakat yang berjualan di sekitar jembatan tersebut. Dalam penerapannya, jika dilihat dari kasus yang ada dalam hal pengelolaan, masih terlihat adanya kekurangan seperti kurang teraturnya penempatan dari para pedagang tersebut.

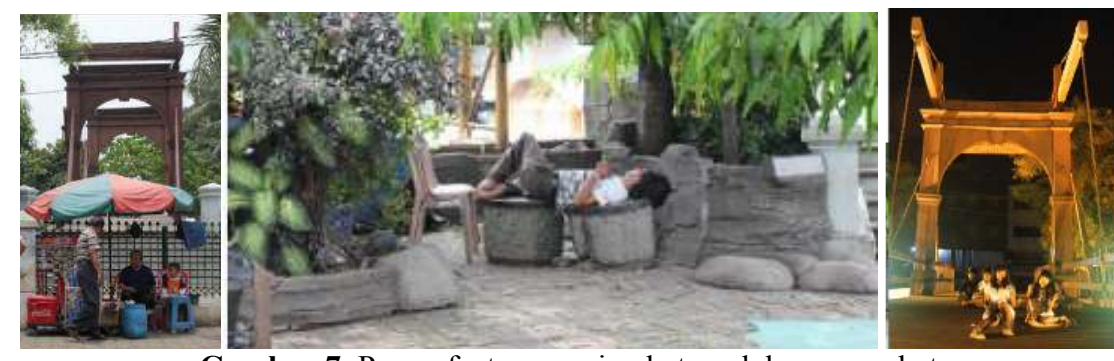

Gambar 7. Pemanfaatan area jembatan oleh masyarakat

Ditemukannya peran serta masyarakat sekitar yang menikmati fasilitas yang ada pada jembatan tersebut. Dari adanya masyarakat yang tertidur. Sampai adanya aktifitas bermain anak pada malam hari. Menunjukkan bahwa Jembatan Kota Intan memiliki potensi untuk dinikmati oleh masyarakat luas. Karena segala macam aktifitas yang terdapat pada jembatan tersebut, mampu memberikan nilai lebih yang tidak hanya sekedar menampilkan objek jembatan.

\section{Pembahasan}

\section{Sistem mekanis jembatan kota intan sebagai daya tarik}

Daya tarik yang dihasilkan dari adanya jembatan kota intan sendiri adalah menghadirkan suatu objek berupa jembatan hasil dari penerapan suatu objek yang berada di eropa dan disesuaikan dengan kondisi yang ada di Indonesia. Dari rancangan yang berada eropa meliputi fungsi awalnya sebagai gerbang dari sebuah benteng yang dibangun oleh VOC. Sampai menjadi objek wisata sejarah yang saat ini dinikmati. Sebagai objek wisata sejarah, selain fungsi awalnya jembatan tersebut juga memiliki sejarah tersendiri yaitu untuk saat ini diketahui bahwa merupakan jembatan gantung tertua yang dibangun pada tahun 1628, dibandingkan dengan Jembatan yang dibuat di Amsterdam sendiri (magere brug) pada tahun 1634. 

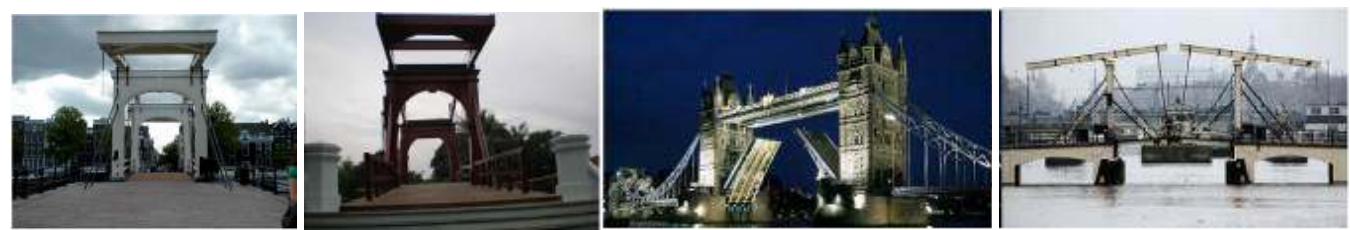

Gambar 8. Daya Tarik Objek Wisata Jembatan

Sebagai suatu jembatan yang memiliki sistem mekanis, Jembatan kota intan memiliki potensi yang cukup baik dalam menjadikannya sebagai objek wisata sejarah yang memiliki unsur teknologi di dalamnya. Karena dengan adanya sistem mekanis, jembatan tersebut juga sudah menghadirkan suatu atraksi yang berkaitan dengan menghadirkan suasana yang ada jika dihubungkan dengan fungsi dan sejarah dari jembatan tersebut. Karena dengan adanya atraksi tersebut secara tidak langsung juga telah menjadikan adanya sesuatu yang dilihat oleh pengunjung disamping objek jembatan sendiri. Sebagai bahan perbandingan yang ada saat ini. Jembatan yang memiliki konsep yang sama seperti jembatan yang berada di Inggris (Tower Bridge) menawarkan kepada para turis untuk menambah pengetahuannya mengenai cara kerja jembatan dan informasi mengenai sejarah pembuatannya. Hal yang sama sebenarnya mampu diterapkan pada Jembatan kota Intan. Karena di sekitar dari jembatan tersebut terdapat potensi yang bisa dimaksimalkan untuk menjadikannya memiliki daya tarik.

\section{KESIMPULAN DAN SARAN}

Kesimpulan

Keberadaan Jembatan Kota Intan yang merupakan suatu objek wisata sejarah didukung dari adanya suasana sebagai objek wisata, posisinya yang berada di suatu kawasan wisata yang telah ditetapkan oleh pemerintah daerah. Kondisi lingkungan yang kurang memadai menjadikan berkurangnya daya tarik. Dukungan dari masyarakat sekitar yang menjalankan suatu aktifitas tanpa merusak objek jembatan telah memperkuat mengenai diterimanya keberadaaan jembatan. Dengan adanya pengelolaan yang dilakukan secara bersama, maka jembatan kota intan mampu menjadi suatu objek wisata sejarah secara lengkap. Dijadikannya jembatan tersebut menjadi suatu tempat dalam mengadakan suatu acara, telah menjadikannya jembatan tersebut memiliki nilai tersendiri sebgai objek wisata.

Sistem mekanis dapat menjadi nilai tambah yang dapat dimanfaatkan dan memaksimalkan suatu kondisi yang ada pada objek wisata. Dengan adanya sistem mekanis dalam suatu objek mampu menjadikannya memiliki nilai tambah berupa daya tarik selain sebuah sejarah yang terdapat pada objek tersebut. Representasi dari sebuah objek wisata sejarah salah satunya adalah menghadirkan suasana yang dibuat sedemikian rupa agar mewakili kondisi awalnya. Suatu sistem mekanis dapat menjadi maksimal untuk sebuah objek melalui suatu sistem yang menggerakkan jembatan kota intan. Dan secara langsung telah memaksimalkan sumber daya yang terdapat disekitar kawasan jembatan tersebut. Melalui pelaksanaan yang baik yang didukung oleh suasana kawasan seperti keberadaan sarana transportasi sebagai salah satu cara untuk mencapai objek wisata tersebut serta pemanfaatan manusia sebagai tour guide didalamnya, akan menjadi daya tarik tambahan yang mendukung dalam sistem mekanis suatu jembatan.

\section{Saran}

Berdasarkan dari kesimpulan yang ada, untuk pengembangan lebih lanjut. Saran yang dapat membantu akan dibagi menjadi dua yaitu saran umum dan saran spesifik. Untuk saran umum, -Masyarakat umum dapat tetap memperhatikan dan menjaga kondisi lingkungan sekitar jembatan kota intan. Sebagai salah satu cara untuk menghargai cagar budaya yang ada di Jakarta. 
-Masyarakat yang memiliki kepentingan komersil seperti berdagang sebaiknya lebih menata posisi dari tempat yang mereka gunakan yang bersifat sementara atau permanen untuk memberikan akses kepada pengunjung.

-Masyarakat khususnya penduduk yang berada sekitar kawasan harus mampu mengelola dan menjaga objek jembatan kota intan di dalam kawasan wisata, mulai dari penataan lingkungan.

- Serta keterlibatan dari wisatawan sedapat mungkin mampu membantu untuk memberikan daya tarik kepada pengunjung agar Jembatan Kota Intan lebih dikenal atau mudah untuk dilihat.

Dari keempat saran umum, disertakan juga saran khusus yang dapat berguna untuk kalangan tertentu yang secara lagsung berhubungan dengan Jembatan Kota Intan yaitu:

-Untuk pihak penjaga perlu memperhatikan kembali kondisi fasilitas yang perlu diperbaiki pada Jembatan Kota Intan dan bisa dimulai dari menghadirkan kondisi yang layak untuk objek wisata sejarah seperti memperbaiki bagian jembatan yang rusak menggunakan bahan dan bentuk yang sama seperti kondisi terdahulu.

-Perlu adanya tambahan aktifitas yang dilakukan oleh pihak penjaga yang tidak hanya difungsikan sebagai penjaga objek wisata namun juga menjadikannya seorang operator. Karena dengan menjadikannya seorang operator yang mampu menggerakkan sebuah jembatan maka dibutuhkan juga pengetahuan mengenai sistem mekanis jembatan.

-Perlu adanya sarana penunjang berupa alat promosi yang lebih baik untuk menguatkan daya tarik yang akan dihasilkan oleh jembatan tersebut.

-Pihak pemerintah daerah sebagai pembuat kebijakan dan pembangunan, agar melakukan evaluasi menyeluruh sampai pada penggunaan untuk mengembalikan suasana objek jembatan sebagai objek wisata sejarah sehingga pengembangan objek wisata tidak hanya terfokus di satu tempat saja.

-Perlu adanya kordinasi antara pemerintah daerah dengan pihak yang langsung terlibat dengan objek wisata jembatan kota intan serta pihak yang berwenang dan mampu dalam mengurus suatu objek wisata sejarah agar lebih dimaksimalkan dan tidak terjadi kesalahan dalam mengembalikan kondisi jembatan seperti yang diinginkan.

\section{Acknowledgement}

Ucapan terima kasih saya ucapkan kepada Tuhan Yang Maha Esa atas kesehatan yang selalu diberikan olehNya, dan kepada Pihak Universitas Mercu Buana serta Pusat Penelitian Universitas Mercu Buana yang telah membantu dalam memberikan dana untuk pelaksanaan penelitian ini. Selain itu juga ucapan terima kasih kepada Bapak Dr Ir. M. Syarif Hidayat, M.Arch., Dr.Ir. Budi Susetyo, MT. Ibu Dr. Ir. Tin Budi Utami, MT, Dr. Ir. Resmi Bestari Muin, MS Sebagai reviewer dari pihak Universitas Mercu Buana yang telah memberikan kesempatan kepada saya untuk dapat melaksanakan penelitian ini. Dan kepada bapak penjaga Jembatan kota intan yang telah meluangkan waktu dan memberikan keterangan yang berguna untuk penelitian ini serta keluarga atas do'a dan supportnya dalam penyelesaian penelitian ini.

\section{REFERENSI}

Burhan, B. (2004). Metodologi penelitian kuantitatif. Jakarta: Kencana Prenada Media Group. Dimyati, E. (2010). Panduan sang petualang: Wisata Kota Tua Jakarta. Jakarta: Gramedia Pustaka Utama.

Kriyantono, R. (2006). Riset komunikasi. Jakarta: Kencana Prenada Media Group.

Pedoman pemintakatan benda (2006). Pedoman pemintakatan benda cagar budaya dan situs, Direktorat Peninggalan Purbakala Direktorat Jenderal Sejarah dan Purbakala. Jakarta: Departemen Kebudayaan dan Pariwisata Kota Jakarta. 
Robert, D. (2011). Making things move: DIY mechanisms for inventors, hobbyists, and artists. New York: McGraw Hill.

Sachari, A. \& Sunarya, Y, Y. (2002). Sejarah perkembangan desain dan dunia kesenirupaan di Indonesia. Bandung: Penerbit ITB.

Sejarah perkembangan kota. 2006. Sejarah perkembangan kota Jakarta. Jakarta: Pemerintah Daerah Ibukota Jakarta.

Sugiyono. (2005). Memahami penelitian kualitatif. Bandung: Penerbit Alfabeta.

Winandari, M, I, R. (2010). Karakter arsitektur kota: metode pencarian identitas kota. Jakarta: Universitas Trisakti. 